\title{
Periphytic algae of the Garças Lake, Upper Paraná River floodplain: comparing the years 1994 and 2004
}

\author{
Murakami, EA. ${ }^{\mathrm{a} *}$, Bicudo, DC. ${ }^{\mathrm{b}}$ and Rodrigues, $L .^{\mathrm{a} *}$ \\ aDepartamento de Biologia - Nupélia - PEA, Universidade Estadual de Maringá - UEM \\ Av. Colombo, 5790, CEP 88720-900, Maringá, PR, Brazil \\ ' Instituto de Botânica, Secretaria do Meio Ambiente, CP 4005, \\ CEP 04301-012, São Paulo, SP, Brazil \\ *e-mail: elizamurakami@gmail.com, lrodrigues@ nupelia.uem.br \\ Received November 7, 2008 - Accepted March 4, 2009 - Distributed June 30, 2009
}

(With 4 figures)

\begin{abstract}
The changes imposed by dams on hydrological regime, water transparence and nutrient concentrations downstream affect biodiversity in relation to species richness and specific composition of the community. The aim of this work was evaluate this effect on periphyton, comparing richness and composition of periphytic algae in the Garças Lake, Upper Paraná River floodplain, between the years 1994, before construction of the Porto Primavera Reservoir, and after its operation in 2004. This floodplain lake showed an increase in species, from 113 in 1994 to 159 in 2004. A few species, however, were common during the last year, dominated by Zygnemaphyceae and some Bacillariophyceae species. The increase in algal diversity in 2004 may be the result of the ability of the system to adapt to environmental changes. However, the large change in the periphyton species composition suggests further impacts on the food web, demanding continuity of long-term studies in order to determine their consequences on the biodiversity as a whole.
\end{abstract}

Keywords: periphyton, stability, floodplain, species richness, species composition.

\section{Algas perifíticas da Lagoa das Garças, planície de inundação do Alto Rio Paraná: comparação entre os anos de 1994 e 2004}

\begin{abstract}
Resumo
As mudanças impostas pela formação de reservatórios afetam a biodiversidade das algas perifíticas em relação à composição e riqueza de espécies. O objetivo deste trabalho foi comparar a riqueza e composição de espécies de algas perifíticas na Lagoa das Garças, planície de inundação do Alto Rio Paraná, entre os anos de 1994, antes da construção do reservatório de Porto Primavera, e em 2004, após seu funcionamento. Para a lagoa registrou-se um aumento na riqueza de 113 espécies em 1994, para 159 espécies em 2004. Contudo, poucas espécies foram comuns, sendo dominadas por Zygnemaphyceae e Bacillariophyceae. O aumento na riqueza de algas em 2004 pode estar indicando a capacidade do sistema em adaptar-se às alterações ambientais, com possíveis alterações na cadeia alimentar. Considera-se fundamental a continuidade de estudos de longo prazo para avaliar as conseqüências da alteração na riqueza e composição de espécies de algas perifíticas para a estrutura e o funcionamento da planície como um todo.
\end{abstract}

Palavras-chave: perifíton, estabilidade, planície de inundação, riqueza, composição de espécies.

\section{Introduction}

The relationship between diversity of an ecological community and its stability is not clear, and has been the subject of numerous debates and considerable research (Pielou, 1983; Colinvaux, 1986; Odum, 1989; Lampert and Sommer, 1997; Townsend et al., 2006). Furthermore, the importance of the term stability has led to the use of different meanings. For Pielou (1983), stability is the tendency of the community composition to remain constant. Colinvaux (1986) relates stability to ecosystem resilience (the ability of the system to, under stress, re- turn to its original state when the stress is removed), and considers an ecosystem "stable" when the probability of species extinction is low.

"Stability" may be defined as the persistence of the system structure (i.e., an ecosystem, community, or organism) over time, the ability of populations to withstand disturbances without marked changes in composition, and the tendency to remain in, or return to, a stable state (Glossário, 1997). Thus, "stability" may be extended in various ways, for example, as persistence, resistance, 
and resilience (Odum, 1988; 1989; Begon et al., 1996; Colinvaux, 1993; Lampert and Sommer, 1997; Townsend et al., 2006).

Persistence refers to the period during which a community remains relatively intact, neither losing nor gaining species (Colinvaux, 1993). Resistance describes the ability to avoid deviation from a stable state (Begon et al., 1996), retaining the same species despite disturbances (Odum, 1989). A community may be considered resilient when it rapidly returns to its original or similar state after it has been altered (Odum, 1989; Colinvaux, 1993; Townsend et al., 2006). Odum (1989) suggests that the type of stability of resilience is favored by the presence of a variety of species within an ecosystem. Lampert and Sommer (1997) also use terms such as "constancy" (absence of alteration in the number of individuals, biomass, number of species, etc.) and "elasticity" (ability to return to a static condition after having deviated from it) as types of stability.

The Upper Paraná River floodplain is characterized by a wide variety of environments (such as open and closed lakes, channels, and rivers, among others), as well as hydrological cycles, with periods of both high and low waters. These cycles vary from year to year, not only in periodicity, but also in duration (Thomaz et al., 2007). The flood pulses can determine the spatial and temporal variation of biotic and abiotic limnological factors (Junk et al., 1989; Thomaz et al., 2004a; 2007). Rodrigues and Bicudo (2001a) stated that the hydrological regime constitutes the principal driving force for periphyton structuring in the Upper Paraná River floodplain, being mostly pronounced in lentic systems. Agostinho et al. (2008) emphasize the importance of the natural hydrological regime for the high diversity of floodplains.

The Upper River Paraná floodplain has suffered the influence of dams located on the main channel and in large tributaries. The operation of these dams has altered the water level fluctuation and periodicity of the hydrological regime (Agostinho et al., 2004; Thomaz et al., 2004a; 2007; Souza Filho, 2009). As a result, flow rate, sediment transportation, and bank erosion in the floodplain have been drastically changed (Souza Filho et al., 2004).

The artificial control of the water levels has affected the floodplain biota such as aquatic vegetation, phytoplankton, and fish. Previously emergent aquatic macrophytes predominated, whereas in recent years an increase in submerged species has been observed, probably due to the regulation of the water level and the constant supply of propagules from upstream reservoirs (Thomaz et al., 2004b).

The periphytic community presents characteristics such as sessile habits, short life span, and, compared to other aquatic groups, it is usually richer in species (Lowe and Pan, 1996). Due to these characteristics and the ability to respond to environmental changes and nutrient availability, periphyton has commonly been utilized in ecological studies to environmental changes and nutrient availability (Sládecková, 1962; Wetzel, 1983; McCormick and Stevenson, 1998). Therefore, the purpose of the present study is to compare richness and specific composition of periphytic algae in the Garças Lake in the Upper Paraná River floodplain between the years 1994 (before the construction of the Porto Primavera Reservoir) and 2004 (when the reservoir was in operation). The hypothesis of this study is that the changes imposed by the formation of the Porto Primavera Reservoir have affected the diversity of periphytic algae.

\section{Material and Methods}

\subsection{Study area}

The Upper Paraná River floodplain is located between Porto Primavera Dam and Itaipu Reservoir, extending about $230 \mathrm{~km}$ (Agostinho et al., 2008). Garças Lake is located in the floodplain in the state of Mato Grosso do Sul (22' 43" S and 53' 14" W). It is on the right side of the river, with which it is connected by a narrow channel approximately $100 \mathrm{~m}$ long (Figure 1). It is about $150 \mathrm{~m}$ wide and 2,000 m long, with a mean depth of $2.5 \mathrm{~m}$. The littoral zone is dominated by multispecies stands of aquatic macrophytes, notably the emergent Echhornia azurea Kunth. No submerged macrophytes were present in the lake during the study conducted in 1994 (personal observation by L. Rodrigues). In 2004, however, several submerged species were observed, such as Ludwigia peruviana (personal observation by S. M. Thomaz). According to Thomaz et al. (2004b), submerged macrophytes were rarely observed in the first studies conducted in the floodplain, but were more frequently observed after 1995 in lakes connected to the River Paraná, as is the case of Garças Lake. The following submerged macrophytes have been observed in Garças Lake: Egeria najas, Chara guairensis, and Nitella furcata (Thomaz et al., 2007).

\subsection{Sampling}

Richness and periphytic algae composition in the Garças Lake observed in 1994 (Rodrigues and Bicudo, 2001b) was compared to that in 2004. Only taxa identified to species level were considered. In the study by Rodrigues and Bicudo (2001b), several samples were taken during the high water period (16 and 24 March, and 1 Abril) and low water period (20 and 28 July, and 5 August, total of six samples). In 2004, samples were taken in March, June, September and December (total of 4 samples).

Sampling processing and periphyton removal was identical in both studies. Due to its predominance, Eichhornia azurea petioles were used as a natural substrate. Periphyton was removed from the petioles when mature (Schwarzbold, 1990), using steel blades and distilled water., and conditioned in $150 \mathrm{~mL}$ glass flasks, fixed with Transeau solution.

Species identification was based on classic literature (Anagnostidis and Komárek, 1988; Croasdale and 


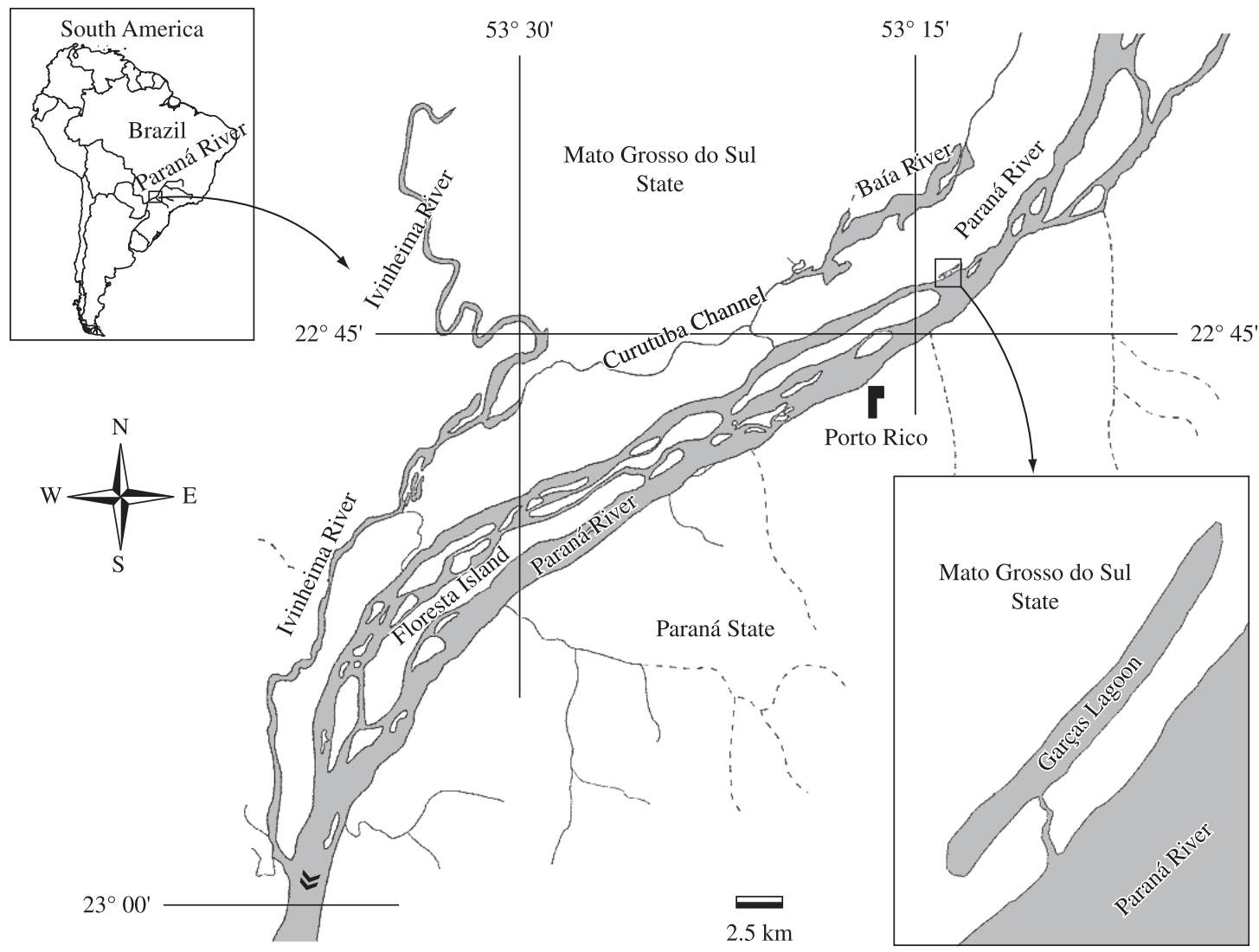

Figure 1. Map showing Garças Lake in the Upper Paraná River floodplain.

Flint, 1986; 1988; Dillard, 1990; 1991; Föster, 1982; Komárek and Anagnostidis, 1986; 1989; Krammer and Lange-Bertalot. 1986; 1988; 1991; Patrick and Reimer, 1966; 1975; Prescott, 1982; Prescott et al., 1981; 1982) as well as other specific and regional literature. Round (1965; 1971) classification system was used, complemented by Bicudo and Menezes (2006).

Abiotic limnological data in 2004 (Appendix 1) were obtained simultaneously with periphytic samples, and supplied by the Nupélia Basic Limnology Laboratory (Nucleus Research in Limnology, Ichthyology, and Aquaculture) at Maringá State University, in the state of Paraná. The data for 1994 were obtained from Rodrigues and Bicudo (2001a).

Water level and precipitation data for the Paraná River were provided by the National Water Agency (ANA), previously known as the National Department of Water and Electrical Energy (DNAEE).

\subsection{Data analysis}

Principal Component Analysis (PCA) was used to rank the months of 2004 (for the present study, data in Appendix 1), as well as the high and low water periods of 1994 (Rodrigues and Bicudo, 2001a) based on abiotic variables. A Correspondence Analysis (CA) was applied to evaluate the similarity of periphytic algae species composition between the years. The concordance between the abiotic data and the specific composition matrices was tested with the Mantel test.

The computer program PC-ORD v4.01 (McCune and Mefford, 1999) was used to perform PCA and CA. Graphics was produced with the program STATISTICA v7.1 (StatSoft, 2005).

\section{Results}

\subsection{Water levels and precipitation on the Paraná River: 1994 and 2004}

In 1994, the high water period (with water levels up to $6 \mathrm{~m}$ ) as well as low waters, were characteristic of the Upper Paraná River floodplain (Figure 2). In that year, mean water level during sampling period was $4.1 \mathrm{~m}$ during high water, and $2.9 \mathrm{~m}$ during low water. In 2004, water levels reached $4.3 \mathrm{~m}$ in April. Mean water levels were $3.0 \mathrm{~m}$ in March and June, and $2.8 \mathrm{~m}$ in September and December.

In 1994, precipitation was consistent throughout the year, whereas in 2004, most of the precipitation occurred in May and in the period from October to the beginning of November (Figure 2). 

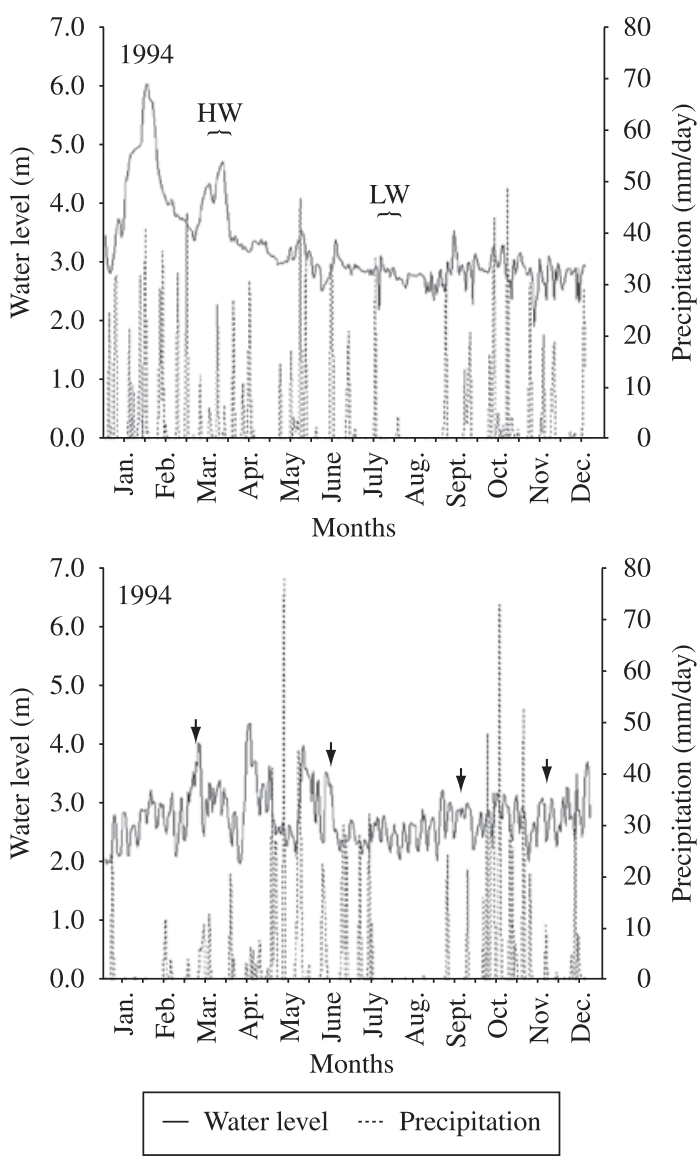

Figure 2. Water and precipitation levels on the Paraná River for the years 1994 and 2004. (Data: ANA). Points HW (high water) and LW (low water) indicate sampling periods in 1994; arrows indicate sampling dates in 2004.

\subsection{Comparison of abiotic parameters}

The Principal Component Analysis (PCA) accounted for $66.2 \%$ of total abiotic data variability on the first two axes. First component $(35.9 \%)$ separated the study periods. The months of 2004 were ordered on the positive side of axis 1 and associated with the higher values of conductivity. On the negative side, the months of 1994 were associated with higher values of ammoniacal nitrogen, phosphorus (orthophosphate and total) and water level (Figure 3, Table 1). On the positive side, of the second component $(30.3 \%)$ were ordered the period of high waters (1994) and the warmer months of the study period of 2004 being associated with higher temperature $(r=0.7)$. On the negative side, the observations from the low-water period (1994) and June (2004) were associated with higher values of nitrate, precipitation and dissolved oxygen.

\subsection{Comparison of the richness and specific composition}

Considering the samplings conducted in Garças Lake (1994 and 2004), 220 species of periphytic al-

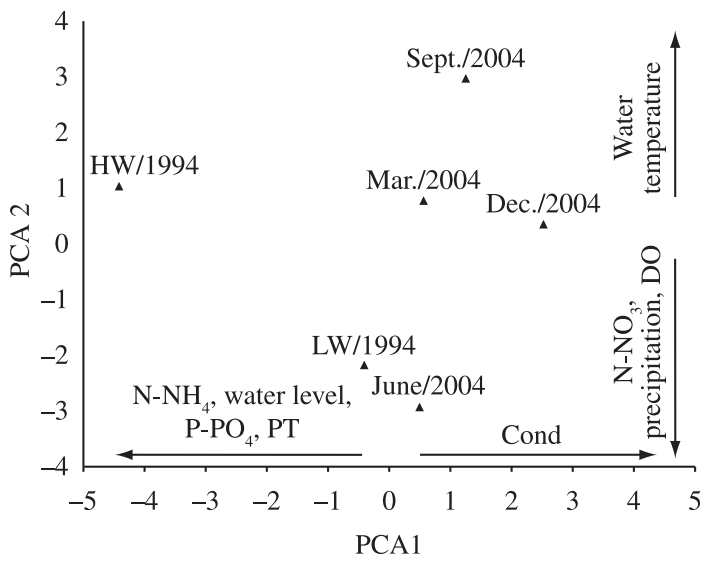

Figure 3. Principal Components Analysis ordination of high water (HW) and low water (LW) periods in 1994*, and the months of March, June, September, and December of 2004. Abbreviations: $\mathrm{N}-\mathrm{NH}_{4}=$ ammoniacal nitrogen; $\mathrm{P}-\mathrm{PO}_{4}=$ orthophosphate; $\mathrm{PT}=$ total phosphorus; $\mathrm{N}-\mathrm{NO}_{3}=$ nitrate; $\mathrm{DO}=$ dissolved oxygen. $*($ Ref.: Rodrigues and Bicudo 2001a).

Table 1. Correlation of abiotic variables with Principal Components 1 and 2.

\begin{tabular}{lrr}
\hline \multirow{2}{*}{ Abiotic variables } & \multicolumn{2}{c}{ Principal component } \\
\cline { 2 - 3 } & $\mathbf{1}$ & $\mathbf{2}$ \\
\hline Water temperature & -0.066 & 0.709 \\
Dissolved oxygen & 0.522 & -0.676 \\
$\mathrm{pH}$ & -0.258 & -0.458 \\
$\mathrm{Conductivity}$ & 0.694 & 0.540 \\
Alkalinity & 0.022 & 0.503 \\
$\mathrm{NT}$ & -0.564 & -0.363 \\
$\mathrm{~N}-\mathrm{NO}_{3}$ & -0.174 & -0.943 \\
$\mathrm{~N}-\mathrm{NH}_{4}$ & -0.923 & -0.318 \\
$\mathrm{PT}$ & -0.799 & 0.452 \\
$\mathrm{PDT}$ & -0.614 & 0.543 \\
$\mathrm{P}^{\mathrm{PO}}{ }_{4}$ & -0.840 & 0.294 \\
$\mathrm{Water}_{\text {level }}$ & -0.918 & 0.034 \\
Precipitation & -0.287 & -0.721 \\
Variation explained & $35.9 \%$ & $30.3 \%$ \\
\hline
\end{tabular}

gae were registered, belonging to 82 genera and 8 classes (85 Zygnemaphyceae, 52 Bacillariophyceae, 35 Chlorophyceae, 33 Cyanophyceae, 8 Xanthophyceae, 3 Euglenophyceae, 2 Chrysophyceae, and 2 Oedogoniophyceae) (Table 2).

Comparing the two years, it was observed an increase from 113 species in 1994 to 159 species in 2004, mainly due to the increase in richness of Zygnemaphyceae species, which nearly doubled (Table 2).

An increase in the species number of Cyanophyceae, Chlorophyceae, and Bacillariophyceae classes was also observed (Table 2). There was, however, a decrease in 
Table 2. Number of periphytic algae species, by class, observed in the Garças Lake, in 1994* and 2004.

\begin{tabular}{lcccccc}
\hline \multirow{2}{*}{ Classes } & \multicolumn{6}{c}{ Number of species } \\
\cline { 2 - 7 } & \multicolumn{2}{c}{ Exclusive } & Common & \multicolumn{2}{c}{ Total } & Total \\
\cline { 2 - 7 } & $\mathbf{1 9 9 4}$ & $\mathbf{2 0 0 4}$ & $\mathbf{1 9 9 4}$ and 2004 & $\mathbf{1 9 9 4}$ & $\mathbf{2 0 0 4}$ & $\mathbf{1 9 9 4}$ and 2004 \\
\hline Cyanophyceae & 9 & 19 & 5 & 14 & 24 & 33 \\
Chlorophyceae & 9 & 18 & 8 & 17 & 26 & 35 \\
Zygnemaphyceae & 20 & 52 & 13 & 33 & 65 & 85 \\
Oedogoniophyceae & 2 & 0 & 0 & 2 & 0 & 2 \\
Euglenophyceae & 2 & 1 & 0 & 2 & 1 & 3 \\
Xanthophyceae & 4 & 1 & 3 & 7 & 4 & 8 \\
Chrysophyceae & 1 & 1 & 0 & 1 & 1 & 2 \\
Bacillariophyceae & 14 & 15 & 23 & 37 & 38 & 52 \\
Total & 61 & 107 & 52 & 113 & 159 & 220 \\
\hline
\end{tabular}

(*)Reference: Rodrigues and Bicudo (2001b).

the species number of Xanthophyceae, and four species were not observed (Characiopsis minor, Characiopsis subulata, Ophiocytium capitatum, and Ophiocytium cohleare).

In 1994 two species of Oedogoniophyceae were observed: Oedogonium reinschi, and Oedogonium warminginianum. However, in 2004, the observation of only vegetative materials, did not allow species identification, and hence this genus was not included in this period. In 1994, the class with the greatest number of species was Bacillariophyceae (37 species), followed by Zygnemaphyceae (33). In 2004, this order was inverted, with a larger number of species of Zygnemaphyceae (65) than Bacillariophyceae (38) (Table 2).

The number of species in common to both years was low, with a total of 52 species $(23.6 \%$ of the total). Furthermore, the majority of the species observed were only found in a particular year: $54.4 \%$ in 1994, and $67.3 \%$ in 2004 (Table 2).

The class with the largest number of species in common (44\%) between both years was Bacillariophyceae (Table 2), with the following species: Achnanthidium minutissimum, Aulacoseira granulata, Cyclotella meneghiniana, Cymbella gracilis, Encyonema mesianum, E. minutum, E. silesiacum, Eunotia flexuosa, E. minor, E. pectinalis, E. sudetica, Fragilaria capucina, Frustulia rhomboides, Gomphonema affine, G. augur, G. gracile, G. parvulum, G. subtile, Navicula cryptocephala, Nitzchia amphibia, N. palea, Sellaphora pupula and Ulnaria ulna.

Zygnemaphyceae presented the largest number of exclusive species, 20 in 1994 and 52 in 2004 (Table 2), showing a low percentage of the species common to both years $(15.3 \%)$.

Cyanophyceae also presented a low percentage of species common to both years (15\%). Thirty-five Chlorophyceae species were identified, and $22.8 \%$ were common to both years. For Xanthophyceae, among eight species registered in the lake, three were common to both years (Characiopsis aquilonaris, C. longipes and C. pyriformis).

The Correspondence Analysis explained $53.5 \%$ of total variance of periphytic algae species composition in the first two axes (Figure 4). Axis 1 (34.9\%) separated the years of study (Figure 4a). Species in Group I (Table 3) were positively correlated with Axis $1(\mathrm{r}=0.998)$. These species were exclusive to 1994, and were observed during high and low water periods. Species of Group II were only observed during 2004, and were negatively correlated with axis $1(r=-0.998)$. The species in these groups were principally Zygnemaphyceae.

Axis 2 (18.5\%) separated, on its positive side, the low water period of 1994 and the months of June and September of 2004, and in its negative side, the high water period and December of 2004 (Figure 4). Species of Group III and IV were positively correlated with axis 2 ( $r=0.592$, and $r=0.504$, respectively). Species in Group III were observed only in June and September of 2004. Species of Group IV were exclusive to the low water period of 1994. Finally, species in Group V were observed during the high water period of 1994 and December 2004 (Table 3).

The Mantel test indicated a positive correlation between the specific composition and abiotic data matrices (Mantel $\mathrm{r}=0.6827, \mathrm{p}=0.0150$ ).

\section{Discussion}

The operation of dams in the Paraná River basin, especially after the construction of the Porto Primavera Dam, has influenced the hydrological cycle on the floodplain, as observed by the sharp difference of water level fluctuation between the years 1994, before the construction, and 2004.

In 2004, the average water level during the days before samplings was below $3.5 \mathrm{~m}$, when the Paraná River has the greatest influence on the plain habitats (Thomas et al., 1997; 2004a). In fact, Principal Component Analysis showed that abiotic limnological characteris- 


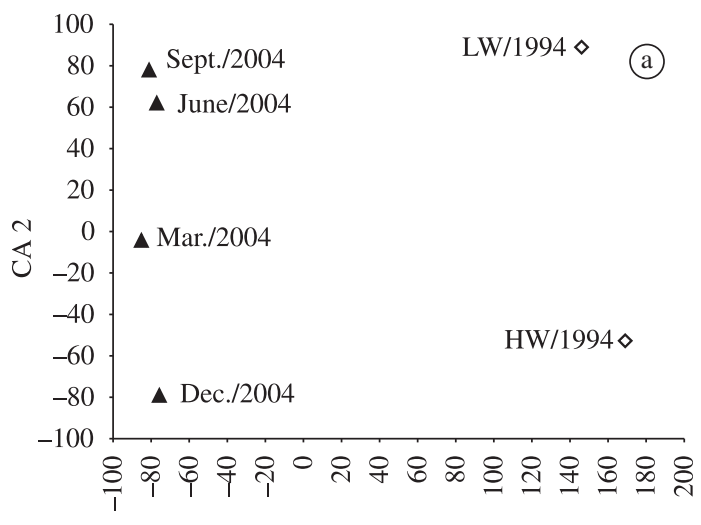

CA 1

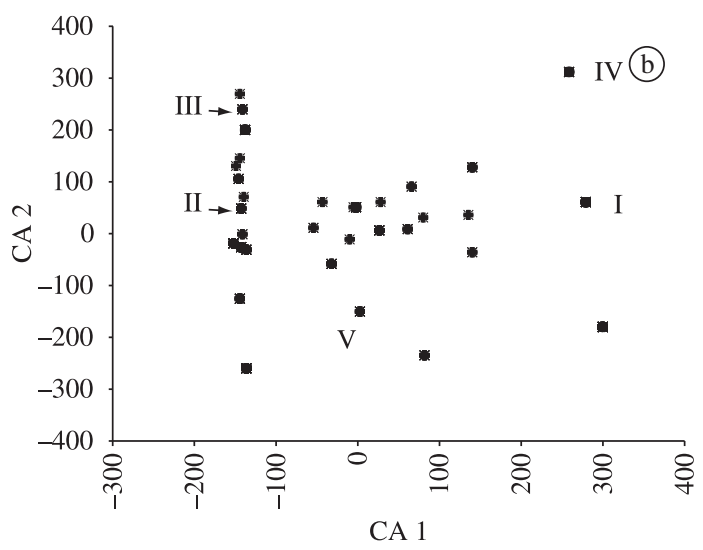

Figure 4. Correspondence Analysis ordination of the species composition of periphytic algae in the Garças Lake, Upper Paraná River floodplain for the years 1994 (HW = high water, and LW = low water)* and 2004. a) Distribution of monthly and yearly scores; and b) Distribution of periphytic algae scores. Species characterizing the different years and periods can be found in Table 3. *Ref.: Rodrigues and Bicudo 2001b.

Table 3. Groups of periphytic algae species more correlated with axis 1 and 2 of the Correspondence Analysis.

\begin{tabular}{cl}
\hline Groups & \multicolumn{1}{c}{ Species } \\
\hline I & Geitlerinema amphibium, Jaaginema geminatum, Oscillatoria sancta, Oedogonium reinschii, \\
& O. warminginianum, Chloromonas paradoxa, Crucigeniella crucifera, Closterium jenerii, \\
& Cosmarium impressulum, C. margaritatum, Cylindrocystis brebissonii, Euastrum pulchellum, \\
& Mougeotia recurva, Netrium digitus, Cyclotella pseudostelligera, Eunotia bilunaris, E. incisa, \\
& E. praerupta, Pinnularia braunii. \\
II & Aphanocapsa cf. grevillei, Pseudoanabaena catenata, Cosmarium granatum, C. vexatum, \\
& Euastrum denticulatum, Onychonema lavae, Eunotia camelus, Gomphonema brasiliense, \\
& G. truncatum. \\
III & Leptolyngbya perelegans, Tetraedron mininum, Cosmarium phaseolus, Gomphonema augur \\
& var. turris. \\
IV & Leibleinia epiphytica, Phormidium foreaui, Pediastrum duplex, Actinotaenium curcubitinum, \\
& Closterium navicula, Staurodesmus dickei, Euglena acus, Anomoeoneis vitrea, Eunotia \\
& lineolata e Navicula viridula. \\
V & Merismopedia punctata, Ankistrodesmus fusiformis, Cosmarium pseudopyramidatum, \\
& Staurastrum leptocladum.
\end{tabular}

tics for the months of 2004 were close to those of the low water period of 1994.

According to Thomaz et al. (2004a), despite the influence of reservoir cascades upstream, there still existed seasonality in the limnological characteristics related to the fluctuations in water level before the formation of the Porto Primavera Reservoir. After the operation of this reservoir, not only the seasonal water level changed but also Secchi depth and water phosphorus concentrations.

The Garças Lake, in the Upper River Paraná floodplain, showed a high diversity of periphytic algae in 1994. Rodrigues and Bicudo (2004) observed high richness since the initial stages of colonization of artificial substrate, indicating a high diversity of periphytic algae in the littoral regions of the floodplain. Among the tree environments studied (lentic, semilotic, and lotic) in 1994, the greatest richness was observed in Garças Lake, most probably related to the presence of aquatic mac- rophytes, which support habitat diversity, and the weak current (Rodrigues and Bicudo, 2004).

Comparing periphytic algae communities of 1994 and 2004 , only few species were common $(23.6 \%$ of the total observed species). Furthermore, 61 species were exclusive to 1994 . Thus, this community did not present stability in terms of persistence and constancy as defined by Colinvaux (1993) and Lampert and Sommer (1997), or resistance (Odum, 1989; Begon et al., 1996), subsequent to the construction of the Porto Primavera Dam.

Approximately half of the species common to both years belong to the class Bacillariophyceae. Many species of pennate diatoms present specialized structures for fixation to substrate, such as mucilaginous stalks (Gomphonema), gelatinous matrices (Cymbela, Encyonema, Frustulia and Navicula), and rosette shapes attached apically by small mucilaginous pads (Eunotia and Fragilaria) (Hoagland et al., 1982). Furthermore, 
diatoms are rapid and efficient colonizers. These characteristics give them the competitive advantage in establishing themselves on substrates compared to species from other classes.

There was an increase in richness of periphytic algae in the lake in 2004, with 107 species not present in 1994. This indicates the capacity of a new community to get established despite environmental changes. Periphytic algae communities may be more resilient in heterogeneous rather than in homogeneous environments because species diversity increases the efficient use of available resources (Stevenson, 1997). The community cannot, however, be described as "resilient" (Odum, 1989; Colinvaux, 1993; Townsend et al., 2006), nor as "elastic" (Odum, 1988; Lampert and Sommer, 1997), as it did not return to the previous specific composition. In fact, a marked difference was observed between the years, and based on the Correspondence Analysis of the specific composition, species of Group I and II were exclusive to each year (1994 and 2004, respectively) and strongly correlated with Axis 1 of the CA.

According to Rodrigues and Bicudo (2001b), periphytic algae composition was strongly influenced by the hydrological cycle, presenting greater species richness during high waters. In 2004, species composition differed the most in December and the least in June and September.

The construction of the Porto Primavera Dam also influenced phosphorus concentrations (Thomaz et al., 2004a). In this study, lower concentrations of ammoniacal nitrogen, orthophosphate, and total phosphorus were observed in 2004, contrasting to observations for the high water period in 1994. Studies such as those by King et al. (2000), Winter and Duthie (2000), and Munn et al. (2002) indicate that phosphorus is an important variable in discussing species distribution.

The greatest species richness of periphytic algae observed in 2004, mainly due to the contribution of Zygnemaphyceae species. Fifty two species recorded in 2004 were not present in 1994. The majority of Zygnemaphyceae taxa inhabit oligotrophic to mesotrophic habitats (Coesel, 1996). In addition to Zygnemaphyceae, some Bacillariophyceae species, such as Cymbella affinis and Gomphonema clevei, which were observed only in 2004, are also good indicators of low orthophosphate and total phosphorus concentrations (Winter and Duthie, 2000; Munn et al., 2002). Furthermore, Coesel and Wardenaar (1990), in experiments with Zygnemaphyceae, demonstrated greater growth under high temperatures, with optimal growth temperature in the range of $25-30{ }^{\circ} \mathrm{C}$. According to PCA, water temperature during the samplings of 2004 was only low in June. So, high temperatures liked favored Zygnemaphyceae richness during this year.

Zygnemaphyceae species do not present specialized structures for fixation to substrates, but they are favored by environments with high quantities of macrophytes. According to Thomaz et al. (2004b), emergent macro- phytic species predominate in the floodplain, but recently, an increase in submerged species has been observed in lakes connected to the Paraná River and in other environments on the floodplain where water flow is low. The increase in submerged macrophytes coincides with the stabilization of water levels and the increase in the water transparency, both caused by the cascades of dams upstream (Thomaz et al., 2004b).

Despite having carried out samplings of periphytic algae on a specific macrophyte (E. azurea), the increase in macrophyte diversity, along with the presence of species that had not previously been found in the Garças Lake nor in the floodplain as a whole, may have contributed to the establishment of new periphyton species, especially Zygnemaphyceae species. Furthermore, the absence of high water period with large water level differences in 2004 may favored the establishment of Zygnemaphyceae species, which weakly adhere to substrates.

It is important to note that several species recorded in 1994 were not found in 2004. Therefore, present results indicated that richness and specific composition were altered as a result of the changes imposed by the construction of the Porto Primavera Dam.

As algae are the basis of the food chain, it is important to monitor the consequences the periphyton biodiversity change. Alteration in the specific composition of periphytic algae can affect other ecological groups in the system. According to Agostinho et al. (2004), the regulation of water flow by upstream dams has modified the structure and function of the Upper Paraná River floodplain and negatively impacted the regional biodiversity.

Thus, the continuity of long-term studies to determine the impact of the alterations in richness and species composition of periphytic algae on the structure and functioning of the floodplain as a whole is essential.

Acknowledgements - This study is part of Projeto PELD (Pesquisas Ecológicas de Longa Duração/CNPq, "A Planície Alagável do Alto Rio Paraná" - Site 6). Thanks are due to Nupélia for their technical and scientific expertise; to CAPES for the doctorate scholarship to the first author; to Dr. Sidinei Magela Thomaz, for providing aquatic macrophyte data; and to Rodrigo Fernandes, doctorate student, for assistance with the statistical analysis.

\section{References}

AGOSTINHO, AA., PELICICE, FM. and GOMES, LC., 2008. Dams and the fish fauna of the Neotropical region: impacts and management related to diversity and fisheries. Revista Brasileira de Biologia = Brazilian Journal of Biology, vol. 68, no. 4, p. 1119-1132

AGOSTINHO, AA., THOMAZ, SM. and GOMES, LC., 2004. Threats for biodiversity in the floodplain of the Upper Paraná River: effects of hydrological regulation by dams. Ecohydrology \& Hydrobiology, vol. 4, no. 3, p. 255-268.

ANAGNOSTIDIS, K. and KOMÁREK, J., 1988. Morden approach to the classification system of Cyanophytes 3 Oscillatoriales. Archiv Hydrobiology Supplement, vol. 80, no. $1-4$, p. 327-472. 
BEGON, M., HARPER, JL. and TOWNSEND, CR., 1996. Ecology: individuals, populations and communities. 3ed. Oxford: Blackwell Science. 1068p.

BICUDO, CEM. and MENEZES, M., 2006. Gêneros de algas de águas continentais do Brasil. São Carlos: RIMA. 489p. Chave de identificação e descrições.

COESEL, PFM. and WARDENAAR, K., 1990. Growth responses of planktonic desmid species in a temperature: light gradient. Freshwater Biology, vol. 23, no. 3, p. 551-560.

COESEL, PFM., 1996. Biogeography of desmids. Hydrobiologia, vol. 336, p. 41-53.

COLINVAUX, P., 1986. Ecology. New York: John Wiley \& Sons, Inc. 725p.

$688 \mathrm{p}$.

1993. Ecology 2. New York: John Wiley \& Sons, Inc.

CROASDALE, H. and FLINT, EA., 1986. Flora of New Zealand: freshwater Algae, Chlorophyta, desmids. Wellington: Government Printer. 132p.

DILLARD, GE., 1990. Freshwater Algae of the Southeastern United States. Part 3. Chrolophyceae: Zygnematales: Mesotaeniaceae and Desmidiaceae (Section 1). Berlin: Cramer. 172p. Bibliotheca Phycologica.

GLOSSÁRIO DE ECOLOGIA, 1997. 2. ed. rev. e ampl. São Paulo: ACIESP. 352p. Publicação ACIESP, no. 103.

HOAGLAND, KD., ROEMER, SC. and ROSOWSKI, JR., 1982. Colonization and community structure of two periphyton assemblages, with emphasis on the diatoms (Bacillariophyceae). American Journal of Botany, vol. 69, no. 2, p. 188-213.

JUNK, WJ., BAYLEY, PB. and SPARKS, RE., 1989. The flood pulse concept in river-floodplain systems. Canadian Special Publication of Fisheries and Aquatic Science, vol. 106, p. $110-127$.

KING, L., BARKER, P. and JONES, RI., 2000. Epilithic algal communities and their relationship to environmental variables in lakes of the English Lake District. Freshwater Biology, vol. 45 , no. 4 , p. 425-442.

KOMÁREK, J. and ANAGNOSTIDIS, K., 1986. Modern approach to the classification system of Cyanophytes 2: Chroococcales. Archiv Hydrobiology Supplement, vol. 73, no. 2 , p. $157-226$.

KRAMMER, K. and LANGE-BERTALOT, H., 1986. Bacillariophyceae: Naviculaceae. In ETTL, H., GERLOFF, J., HEYNING, H. and MOLLENHAUER, D. (Eds.). Süsswasser flora von Mitteleuropa. Stuttgart: Gustav Fischer. 876p. vol. 2, no. 1

1988. Bacillariophyceae: Bacillariaceae, Epithemiaceae, Surirellaceae. In ETTL, H., GERLOFF, J., HEYNING, H. and MOLLENHAUER, D. (Eds.). Süsswasser flora von Mitteleuropa. Stuttgart: Gustav Fischer. 596p. vol. 2, no. 2 .

1991. Bacillariophyceae: Centrales, Fragilariaceae, Eunotiaceae. In ETTL, H., GERLOFF, J., HEYNING, H. and MOLLENHAUER, D. (Eds.). Süsswasser flora von Mitteleuropa. Stuttgart: Gustav Fischer. 576 p. vol. 2, no. 3.

LAMPERT, W. and SOMMER, U., 1997. Limnoecology: the ecology of lakes and streams. New York: Oxford University Press. 382p.
LOWE, RL. and PAN, Y., 1996. Benthic algal communities as biological monitors. In Stevenson, RJ., BOTHWELL, ML. and LOWE, RL. (Eds.). Algal ecology: freshwater benthic ecosystems. San Diego: Academic Press. p. 705-739.

McCORMICK, PV. and STEVENSON, RJ., 1998. Periphyton as a tool for ecological assessment and management in the Florida everglades. Journal Phycology, vol. 34, no. 5, p. 726-733.

McCUNE, B. and MEFFORD, MJ., 1999. Multivariate analysis of ecological data. Oregon: MjM Software. Version 4.0.

MUNN, MD., BLACK, RW. and GRUBER, SJ., 2002. Response of benthic algae to environmental gradients in a agriculturally dominated landscape. Journal North American Benthological Society, vol. 21, no. 2, p. 221-237.

ODUM, E., 1988. Ecologia. Rio de Janeiro: Ed. Guanabara Koogan. 434p.

1989. Ecology and our endangered life-support systems. Stanford: Sinauer Associates. 283p.

PATRICK, R. and REIMER, CW., 1966. The diatoms of the United States, exclusive of Alaska and Hawaii. Philadelphia: Livingstgon Company. 688p. Monography. vol. 1, no. 13

1975. The diatoms of the United States, exclusive of Alaska and Hawaii. Philadelphia: Livingstgon Company. 213p. Monography. vol. 2, no. 13.

PIELOU, EC., 1983. Population and community ecology: principles and methods. New York: Gordon and Breach. 424p.

PRESCOTT, GW., 1982. Algae of the western great lakes area. Koenigstein; Germany: Otto Koeltz Science Publishers. 977p.

PRESCOTT, GW., CROSDALE, HT. and VINYARD, WC., 1981. A synophysis of North American desmids. Part II. Desmidiaceae: Placodermae. Section 3. In Prescott, GW. (Ed.). Desmidiales. Lincoln: University Nebraska Press. 720p.

1982. A synophysis of North American desmids. Part II. Desmidiaceae: Placodermae. Section 4. In Prescott, GW. (Ed.). Desmidiales. Lincoln: University Nebraska Press. 698p.

RODRIGUES, L. and BICUDO, DC., 2001a. Limnological characteristics comparison in three systems with different hydrodynamic regime in the Upper Paraná river floodplain. Acta Limnologica Brasiliensia, vol. 13, no. 1, p. 39-49.

2001b. Similarity among periphyton algal communities in a lentic-lotic gradient of the upper Paraná river floodplain, Brazil. Revista Brasileira de Botânica, vol. 24, no. 3, p. $235-248$.

, 2004. Periphytic algae. In Thomaz, SM., AGOSTINHO, AA. and HAHN, NS (Eds.). The upper Paraná River and its floodplain: physical aspects, ecology and conservation. The Netherlands: Backhuys Publishers. p. 125-143.

ROUND, FE., 1965. The biology of algae. London: Edward Arnold (Publishers) Ltd. 269p.

1971. The taxonomy of the Chlorophyta, 2. British Phycological Journal, vol. 6, no. 2, p. 235-264.

SCHWARZBOLD, A., 1990. Métodos ecológicos aplicados ao estudo do perifíton. Acta Limnologica Brasiliensia, vol. 3, no. 1, p. 545-592.

SLÁDECKOVÁ, A., 1962. Limnological investigation methods for the periphyton ("aufwuchs") comunity. Botany Review, vol. 28 , no. 2 , p. 286-350. 
SOUZA FILHO, EE., 2009. Evaluation of the Upper Paraná River discharge controled by reservoirs. Revista Brasileira de Biologia = Brazilian Journal of Biology, vol. 69, no. (2 suppl), p. 707-716.

SOUZA FILHO, EE., ROCHA, PC., COMUNELlO, E. and STEVAUX, JC., 2004. Effects of the Porto Primavera dam on physical environment of the downstream floodplain. In Thomaz, SM., AGOSTINHO, AA. and HAHN, NS. (Eds.). The upper Paraná River and its floodplain: physical aspects, ecology and conservation. The Netherlands: Backhuys Publishers. p. 55-74.

StatSoft, INC., 2005. Statistica (data analysis software system). Version 7.1. Available from: <http://www.statsoft.com>. Access in: $12 / 11 / 2008$.

STEVENSON, RJ., 1997. Scale-dependent determinants and consequences of benthic algal heterogeneity. Journal of the North American Benthological Society, vol. 16, no 1, p. $248-262$.

THOMAZ, SM., BINI, LM. and BOZELLI, RL., 2007. Floods increase similarity among aquatic habitats in river-floodplains systems. Hydrobiologia, vol. 579, no. 1, p. 1-13.
THOMAZ, SM., BINI, LM., PAGIORO, TA., MURPHY, KJ., SANTOS, AM. and SOUZA, DC., 2004b. Aquatic macrophytes: diversity, biomass and decompostition. In Thomaz, SM., AGOSTINHO, AA. and HAHN, NS. (Eds.). The upper Paraná River and its floodplain: physical aspects, ecology and conservation. The Netherlands: Backhuys Publishers. p. $331-352$.

THOMAZ, SM., PAGIORO, TA., BINI, LM., ROBERTO, MC. and ROCHA, RRA., 2004a. Limnological characterization of the aquatic environments and the influence of hydrometric levels. In Thomaz, SM., AGOSTINHO, AA. and HAHN, NS. (Eds.). The upper Paraná River and its floodplain: physical aspects, ecology and conservation. The Netherlands: Backhuys Publishers. p. 75-102.

TOWNSEND, CR., BEGON, M. and HARPER, JL., 2006. Fundamentos em ecologia. Porto Alegre: Artmed. 592p.

WETZEL, RG., 1983. Periphyton of freshwater ecosystems. Boston: The Hague. 345p.

WINTER, JG. and DUTHIE, HC., 2000. Epilithic diatoms as indicators of stream total $\mathrm{N}$ and total $\mathrm{P}$ concentration. Journal North American Benthological Society, vol. 19, no. 1, p. 32-49. 
Murakami, EA., Bicudo, DC. and Rodrigues, L.

Appendix 1. Abiotic limnological parameters of the Garças Lake, Upper Paraná River floodplain in 2004.

\begin{tabular}{|c|c|c|c|c|}
\hline Limnological variables & March & June & September & December \\
\hline Water temperature $\left({ }^{\circ} \mathrm{C}\right)$ & 29.5 & 18.9 & 24.4 & 26.5 \\
\hline Dissolved oxygen $\left(\mathrm{mg} \cdot \mathrm{L}^{-1}\right)$ & 6.01 & 7.07 & 3.57 & 5.17 \\
\hline $\mathrm{pH}$ & 6.93 & 6.44 & 5.92 & 5.88 \\
\hline Conductivity $\left(\mu \mathrm{S} . \mathrm{cm}^{-1}\right)$ & 50.4 & 51.6 & 58.2 & 54.7 \\
\hline Alkalinity $\left(\mathrm{mEq} \cdot \mathrm{L}^{-1}\right)$ & 0.32 & 0.24 & 0.35 & 0.33 \\
\hline $\mathrm{NT}\left(\mu \mathrm{g} . \mathrm{L}^{-1}\right)$ & 188.09 & 172.82 & 152.11 & 159.58 \\
\hline $\mathrm{N}-\mathrm{NO}_{3}\left(\mu \mathrm{g} \cdot \mathrm{L}^{-1}\right)$ & 9.70 & 47.13 & 0.20 & 22.42 \\
\hline $\mathrm{N}-\mathrm{NH}_{4}\left(\mu \mathrm{g} \cdot \mathrm{L}^{-1}\right)$ & 7.42 & 15.90 & 5.09 & 0.49 \\
\hline PT $\left(\mu \mathrm{g} . \mathrm{L}^{-1}\right)$ & 24.36 & 12.24 & 19.42 & 9.93 \\
\hline PDT $\left(\mu g . L^{-1}\right)$ & 8.19 & 6.15 & 10.92 & 2.65 \\
\hline $\mathrm{P}-\mathrm{PO}_{4}\left(\mu \mathrm{g} \cdot \mathrm{L}^{-1}\right)$ & n.d.* & n.d.* & 4.05 & n.d.* \\
\hline Water level (m) & 3.05 & 3.04 & 2.77 & 2.84 \\
\hline Precipitation (mm.day ${ }^{-1}$ ) & 0.40 & 6.08 & 0.00 & 1.15 \\
\hline
\end{tabular}

*n.d.: value not detected. 